\title{
Crops Rotation - the Solution of Environmental Problems (a Case Study of Prince Edward Island in Canada)
}

\author{
P. Procházka, H. Řezbová, L. Smutka \\ Faculty of Economics and Management, Czech University of Life Sciences Prague, Czech Republic
}

\begin{abstract}
Anotace
Ostrov prince Edwarda je ve světě známí zejména pro svoji produkci brambor. Zatímco brambory představují velmi zajímavý zdroj př́jmů, jejich produkce je spojena s výraznými dopady na životní prostředí. Hlavní roli v tomto ohledu hrají chemie a hnojiva použité v procesu pěstování brambor. Jejich užití se projevuje výrazným znečištěním vodních zdrojů. Jako odpověd’ na rostoucí znečistění místní vláda navrhla strategii/politiku vedoucí $\mathrm{k}$ redukci negativního vlivu spojeného s produkcí brambor na kvalitu vodních zdrojů. Jedna z nových politik (povinné střádání plodin) je analyzována v tomto článku. Analýza vlivu této politiky je provedena prostřednictvím aplikace „optimal control theory“ a dynamického programování. Poznatky plynoucí z kointegračního modelu poukazují na vliv zemědělství jakožto jednoho z významnější zdrojů znečištění vodních zdrojů. Je poskytnut statistický důkaz, že politika týkající se ochrany vodních zdrojů, musí být zaměřená právě na proces produkce brambor. Nicméně je nutno zdůraznit, že implementace environmentálně orientovaných opatření (povinná rotace plodin) se negativně promítá do ekonomiky farem.
\end{abstract}

\section{Klíčová slova}

Teorie optimální kontroly, povinná rotace plodin, politika životního prostředí, zemědělství, producenti brambor, ekonomické dopady.

\begin{abstract}
Prince Edward Island (PEI) is well known around the world for its potato industry. While economically beneficial for PEI, potato production contributes to its environmental deterioration. This can be attributed to the high use of chemicals and fertilizers in the production, which leads to the pollution of PEI's watercourses. In response to the environmental crisis, the PEI provincial government proposed several land use policies to mitigate the negative influence of potato production on water quality. One of the policies that is analyzed in this paper is a mandated crop rotation. The analysis of the mandatory crop rotation policy is achieved through the application of optimal control theory and dynamic programming. Findings from the co-integration model show that agriculture is most likely responsible for watercourse pollution in PEI. This provides statistical evidence that a policy aimed at water protection, specifically targeting potato land use is necessary. However the application of environmentally friendly approach (mandatory crops rotation) is positive, its negative impact on individual farms economy is evident.
\end{abstract}

\section{Key words}

Optimal control theory, mandatory crop rotation, environmental policy, agriculture, potato producers, economy impact.

\section{Introduction}

In nowadays agricultural sector performance and its relationship with environmental issues are discussed very often. Increasing interference of agriculture with the environment (Clark et al. 2012) has led to a greater concern associated with the external effects associated with agricultural production (Svatoš, 2008). The conducted paper is focused on problems of agricultural activities' impact on living environment. Discussion related to improvement of mutual relationship between agricultural and environmental activities are very dynamic in many countries around the world including the European Union. The paper is based on research conducted by one of the authors during his long-term study stay 
in Canada. The main ambition of the paper is to encourage discussion about the importance of crop rotation both in relation to farming activities and living environment. The conflict between agriculture and living environment is typical for many countries including Canada - as an example of this conflict we can take in consideration the problems existing between farmers producing potatoes and living environment development in the case of Prince Edward Island (PEI), the smallest province of Canada which is known for its clean environment and progressive environmental legislation. For local economy two activities are the most important - agriculture and tourism. Tourism expenditures in 2013 totaled \$295.7 million (Prince Edward Island Provincial Treasury, 2014). Besides tourism that is driven by the natural beauty of PEI, Prince Edward Island is also known for growing potatoes. Agriculture contributed about $\$ 497$ million to PEI's economy, with approximately $50 \%$ of total farm cash receipts being generated by potatoes in 2013 (Statistics Canada, 2014). For many years agriculture and tourism have co-existed with no major disputes. According to e.g. Canadian Broadcasting Corporation (2007a, 2007b, 2007c) agriculture has begun to interfere with tourism and other economy activities, sport fishing etc. in the moment when farmers significantly increased the level of potato production. In surface water, excessive nitrogen and phosphorus levels from agricultural production are assumed to cause three major pollution problems: 1) enrichment of an ecosystem with chemical nutrients; 2) a change in the composition and distribution of flora and fauna in the streams (Government of Prince Edward Island, 1996); and 3) health hazards due to the contamination of wells and other sources of drinking water (PEI Government, 2002). Agriculture in PEI has been blamed in the past two decades for deterioration of an environment that is considered to be one of the best in Canada (Jatoe et al., 2007). This conflict, however, is quite common in Canada, as well as around the world. Famous examples of agricultural interference with the environment include the pollution of Lake Winnipeg (Lake Winnipeg Stewardship Board, 2008) or the Baltic Sea pollution (BAAP, 2003), both caused by agricultural run-off. Increased concerns over the environmental impacts of agriculture have encouraged entreaties throughout the world for agricultural production methods which are more environmentally sustainable. One of the controls that policy makers have implemented to assuage the long-run environmental impacts of agricultural production is the mandated crop rotation. While mandated crop rotations have been used as a common tool for environmental sustainability in the European Union, they were implemented only recently in North America in the province of Prince Edward Island. The aim of the mandatory crop rotation legislation is to reduce environmental pollution associated with potato production by limiting the maximum number of years that potatoes can be grown. Surprisingly, however, as opposed to the European Union, mandated crop rotations met with resistance from PEI farmers. Mandatory crops rotation is affecting farmers' decision making process related to their economy activities. The application of mandatory crops rotation is affecting farmers' production costs and also it has a significant impact on their profitability. The proposed crops rotation models have reduced farmers' crops (potato) production volume by about $20 \%$ (in same cases even more). However mandatory crops rotation has a negative economy impact on farmers and farmers' willingness to apply that model is limited or even negative. It must be emphasized that mandatory crops rotation represents the solution of several problems (environmental pollution management, land quality management etc.). The main motivation of this paper is encouraging discussion related to crops rotation problem.

The papers main goal is to specify the impact of mandatory crops rotation of farming activities in PEI. Main goal is divided into three following sub-goals.

1. The identification of impact of intensive farming on living environment (the impact of intensive potato production on watercourse pollution).

2. The specification of watercourse pollution elimination through the optimal crops rotation.

3. The specification of mandatory crops rotation (different scenarios) impact on farmers' production structure decision making process and their profitability.

\section{Materials and methods}

No statistical evidence was hitherto provided whether agriculture is the only polluter of PEI watercourses. This paper aims to gain insight into the environmental pollution concern in PEI, as well as to analyze why the implementation 
of the mandatory environmental legislation was not supported by PEI potato producers. Environmental pollution in PEI watercourses is analyzed using time series analysis tools. In order to analyze what is causing water pollution in PEI, individual time series are examined for the presence of a unit root. This is done by the Dickey-Fuller test, originally proposed by Dickey and Fuller (1979). The question that arises is why the crop rotation legislation was resisted by potato producers. To answer this question, an optimal control model of PEI potato rotations was developed. Unique to the modeling effort of potato rotations is the fact that the rotations are not fixed; each year, the choice of crop is based on present and future value. Also, a distinction is made between organic nitrogen (modeled as stock) and inorganic nitrogen (modeled as flow). The optimal control model has as its state variable nitrogen stock (that is related to soil organic matter) and nitrogen fertilizer as its control variable.

A continuous optimal control model is presented below:

$$
\begin{aligned}
& \text { Max } U \int_{t=0}^{T}[(\text { piyit }(N t, F i t))-c F i t) x+(\operatorname{piyit}(N t, F i t)) \\
& -c F i t)(1-x)] d t e^{-r t} \\
& N 1=\frac{\delta N 1}{\delta t}=g 1[N(t), F 1(t)] x+g 2[N(t), F 2(t)](1-x) \\
& -\varphi N 1(t) \\
& N 1(0)=N 1, F i \geq 0,0 \leq x \leq 1, \text { and } i=1,2
\end{aligned}
$$

and

$$
N 1(T)=\text { free }
$$

where $U$ is a discounted cumulative performance measure, i.e. profits over the planning horizon. $T$, $p i$ are the prices of the respective crop $i, i=1,2 r>0$ is the private rate of discount, $\mathrm{c}$ is the input price of fertilizer, and N0 is the initial value of nitrogen stock. $N t$ is the value of nitrogen in time $t$, Fit is the value of fertilizer applied to the field at time $t$ for crop $i$, yit represents a yield function of crop ${ }_{\mathrm{i}}$ at time $t, x$ represents a proportion of field devoted to potatoes and $\varphi$ is the rate at which the stock releases nitrogen that is used by the crop. The model hence consists of three control variables $x, F i$ for $i=1.2$, and one state variable $N 1$. The model represents a process in which each year producers are presumed to choose, based on current profit and future conservation value, the most profitable of two crops: potatoes (high valued, high depletion crop); and barley (intermediate valued, intermediate depletion), ryegrass (low valued as it is used as manure, high conservation). The nitrogen cycle is developed to understand peculiarities of PEI potato production, whereas in the optimal control model, it is introduced as the equation of motion (equation 3). Various crops have different biophysical properties that are reflected in the equation of motion and represent residues and their quality. For example, in the case of potatoes where most of the plant is harvested, potatoes return less nitrogen to the soil than they extract. Forage, on the other hand, leaves abundant soil residues and hence contributes to soil organic nitrogen conservation. In order to solve the problem, an empirical discrete time simulation model is provided below (equations 5, 6). A discrete time approach has advantages as it allows the introduction of stochasticity by random price generation and to use computer algorithms to obtain quantitative results.

$$
\begin{aligned}
& \operatorname{Max} \frac{1}{(1+r)^{t}} \sum_{t=0}^{T}(p 1 y 1(N, F)-c F 1+p 2 y 2(N, F) \\
& -c F 2+p 3 y 3(N, F)-c F 3 \\
& \Delta N 1 t=\beta i(F i t-1+N t-1)-\varphi N t-1, N 1=N x
\end{aligned}
$$

where $N$ denotes the nitrogen released from the stock $N 1$ that is made available to the plant, $\varphi$ is the rate at which the stock releases nitrogen that is used by the crop, $\beta$ is the rate at which fertilizer and nitrogen flow from the previous time period, transferred through crop residues into nitrogen stock N1, N10 is the initial nitrogen stock, and $N x$ is the value of initial nitrogen stock. The remaining elements of the equation (equations 5,6) are described in the theoretical optimal control model in the previous section of this paper.

\section{Results and discussion}

An impact of agricultural production on environment and government's reaction

In order to examine the impact of agricultural production upon the environment, nitrogen is analyzed based on the following factors: 1) nitrogen is believed to be a good indicator of the overall impact of agricultural activity on the environment (PEI government, 2002); 2) potato production is characterized by high usage of nitrogen fertilizer while at the same time is of a highly erosive nature; 3) nitrogen is the main fertilizer used in agricultural production to boost crop yields (Fertilizer Institute, 2007); 4) nitrogen pollution can also be linked 
to non-agricultural influences (Crist, Monroe, Poats, 1999); 5) nitrogen in the soil can be related to soil organic matter, an indicator of overall soil quality; and most importantly $\mathbf{6}$ ) during the last thirty years, there has been an alarming increase in nitrogen pollution in PEI watercourses. This is demonstrated in Graph 1. The figure plots the average amount of nitrogen in three PEI streams during the last almost four decades (from the beginning of 70ties) together with three observations from three watersheds in PEI. The figure shows a definitive rise over time. This has led to increasing concern that the pollutants in the streams may be causing environmental damage.

In response to the increased pollutants in PEI watercourses, the Provincial government of PEI set up a commission to study the problem and make recommendations to the Provincial government. This commission produced a report known as the Round Table on Resource Land Use and Stewardship (PEI Government, 1997), hereafter simply called the Round Table. Several recommendations were made in the report; however, in dealing with agriculture, the two that are directly of concern to this research include:

1. The establishment of buffer zones between cultivated agriculture and watercourses; these buffer zones are intended to mitigate pollutant runoff from intensive agriculture into PEI watercourses. Potato producers are offered compensation in the form of subsidies for instituting buffer zones;

2. A mandatory three year crop rotation for potato producers. This rotation mandated that potatoes could only be grown one year in three. The other two years are at the discretion of the producer, but are hoped to include a grain crop (mostly wheat or barley) followed by a forage crop. The Agricultural Crop Rotation Act (ACRA) is the first legislation in North America to directly target pollution from agriculture so that agricultural producers themselves have to bear the costs associated with that decision. Potato producers are not offered any compensation for the implementation of crop rotations. The recommendations of the Round Table were legislated in PEI in the late early millennium. While the general consensus seems to be that the buffer zones have generally been enacted, the same cannot be said for the mandatory crop rotations. The rotations legislation was not supported by potato producers, who argued that the legislation, especially the crop rotation legislation, was unduly restrictive to producer choice, costly to implement, and possibly redundant since farmers were already practicing a three year crop rotation (Canadian Broadcasting Corporation, (2001)).

Time series analysis of watercourses pollution in PEI

In order to examine what is causing the rise in nitrogen levels in PEI watercourses and to analyze the conflict of the agricultural vs. non-agricultural sector, some of the tools of the time series analysis are used. Two candidates selected on the base of available literature sources (increasing potato production and waste management) from both agricultural and nonagricultural sectors are chosen as possible polluters of PEI watercourses. The major cause of increased nitrogen levels is assumed to be

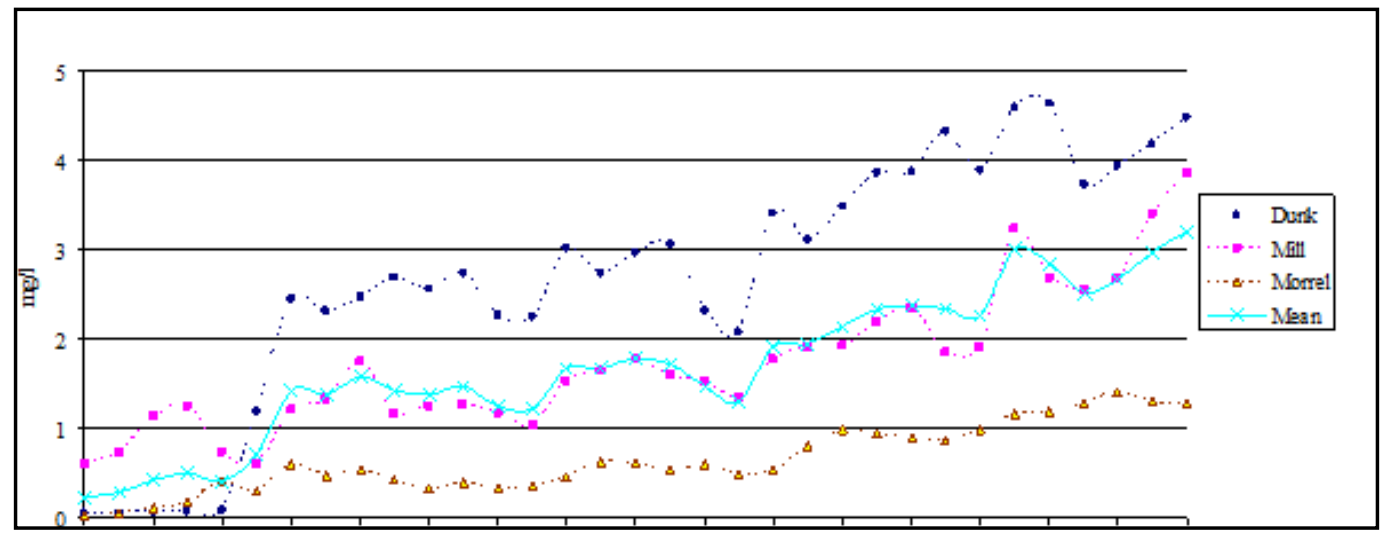

Source: Environment Canada (2015)

Graph 1. Average total nitrogen level in PEI watercourses (30 years development). 
the agricultural industry, especially the intensive cultivation of potatoes. The assumption that primary potato production is the cause of increased pollution on the Island is due to the fact that there has been a large expansion of the potato industry during the last two decades. This expansion has been facilitated by the expansion of processing capacity, since a new processing plant was built by McCains foods and an existing plant was expanded by Cavendish farms during the same time. This led to large areas of land converted into potato production, especially in Eastern PEI. The rise of farmed areas in PEI is certainly consistent with the rise of nitrogen levels presented in Graph 1., but the relationship could be spurious. With respect to nonagricultural influence, for example, Crist, Monroe and Poats (1999) argue that in the rural areas, there are almost no sanitary sewers. The lack of sanitary sewers requires an on-site sewage disposal system. These septic systems may have negative influences upon the environment under certain circumstances. Crist, Monroe and Poats (1999) further argue that there is a major problem associated with septic tanks and water pollution since as many as one-half of all septic tanks in operation are not functioning correctly. Since no data is available on the number of septic tanks in PEI or the quality of septic tanks, another variable has to be chosen to approximate influence of septic tanks upon the environment of PEI. Rural population in PEI is chosen as a proxy variable for the number of septic tanks.

\section{Model and results of watercourses pollution analysis}

In order to analyze what is causing water pollution in PEI, individual time series are examined for the presence of a unit root. This is done by the Dickey-Fuller test. Case 1 of Dickey-Fuller implies that the original time series has a zero mean. Since this does not seem to be plausible for rising nitrogen levels in watercourses of PEI, only Case 2 (intercept, no trend) and Case 4 (intercept, trend) are examined. In Table 1, results of Dickey-Fuller test are presented.
The table indicates that for all variables, existence of a unit root in the series cannot be rejected $t$ the $5 \%$ level of significance. In the non-stationary framework it is true that in order for one time series to explain another time series, they have to be integrated with each other, i.e. there has to be a long-run relationship between two or more series (Granger, 2002). There are several methods on how to test for integration. Park's (1992) canonical integrating regression (CCR) used in this paper extends to more general integrated models, such as the models with structural breaks and the system of regressions given in structural form. Hence, CCR can be used for models with variables which include deterministic as well as stochastic trends. This is important for the case of PEI since there were no reported fish mortalities (as an evidence of living environment improvement) since the end of 2004 due to the change in legislation of buffer zones (Canadian Broadcasting Corporation, 2007c). In order to represent the effects of legislation upon the level of nitrogen, a dummy variable is created so that it takes the value of zero within the analyzed time period before the legislation was changed, and one within the period after the new legislation was introduced. Table 2 presents the findings of an analysis of a possible relationship between the expansion of the PEI potato industry, rural population, and nitrogen pollutants in PEI watercourses using CCR.

The table indicates that the null hypothesis of no integration between nitrogen levels, areas seeded to potatoes, and the dummy variable can be rejected, while it cannot be rejected for population, dummy, and constant variables. Hence, it is concluded from the results of CCR that there is evidence that the rise in nitrogen levels in PEI is related to the expansion of the PEI potato industry, while it is not related to the rural population of PEI. These results further motivate the need to analyze the environmental legislation that was not supported by farmers' groups in PEI.

\begin{tabular}{|l|c|c|c|}
\hline & PEI nitrogen levels & PEI rural population & PEI potato acreage \\
\hline Case 1 (no intercept, no trend) & -1.37 & 0.07 & 1.77 \\
\hline Case 2 (intercept, no trend) & -3.00 & -2.33 & -1.33 \\
\hline Case 4 (intercept, trend) & -3.00 & -2.38 & -2.10 \\
\hline
\end{tabular}

* Level variable from the regression $A y_{t}=\beta_{1} T+\beta_{2} y_{t-1}+\beta_{3} y_{t-1}+v_{t}$, where $T=0$ for Case 1 (no intercept, no trend); $t=1$ for Case (intercept, no trend); and $T=[1, t]$ for Case 4 (intercept, trend) included in the Dickey-Fuller regression.

Source: own processing, 2015 


\begin{tabular}{|l|c|c|c|}
\hline \multirow{2}{*}{ Scenarios } & \multirow{2}{*}{$\begin{array}{c}\text { \# of added } \\
\text { polynomials }\end{array}$} & \multicolumn{2}{|c|}{ H(p,g) test } \\
\cline { 2 - 4 } & $\mathrm{T}^{2}$ & 0.58 & 0.45 \\
\hline \multirow{2}{*}{$\begin{array}{l}\text { Scenario 1 } \\
\text { (acreage, constant, dummy) }\end{array}$} & $\mathrm{T}^{3}$ & 0.59 & 0.75 \\
\cline { 2 - 4 } & $\mathrm{T}^{4}$ & 4.49 & 0.21 \\
\cline { 2 - 4 } & $\mathrm{T}^{2}$ & 5.09 & 0.02 \\
\hline \multirow{2}{*}{$\begin{array}{l}\text { Scenario 2 } \\
\text { (population, constant, dummy) }\end{array}$} & $\mathrm{T}^{3}$ & 7.68 & 0.02 \\
\hline \multirow{2}{*}{$\begin{array}{l}\text { Scenario 3 } \\
\text { (acreage, population, constant, dummy) }\end{array}$} & $\mathrm{T}^{4}$ & 7.92 & 0.05 \\
\cline { 2 - 4 } & $\mathrm{T}^{2}$ & 0.36 & 0.55 \\
\cline { 2 - 4 } & $\mathrm{T}^{3}$ & 2.66 & 0.26 \\
\cline { 2 - 4 } & $\mathrm{T}^{4}$ & 4.69 & 0.19 \\
\hline
\end{tabular}

* Level variable from the regression $A y_{t}=\beta_{1} T+\beta_{2} y_{t-1}+\beta_{3} y_{t-1}+v_{t}$, where $T=0$ for Case 1 (no intercept, no trend); $t=1$ for Case (intercept, no trend); and $T=[1, t]$ for Case 4 (intercept, trend) included in the Dickey-Fuller regression.

Source: own processing, 2015

Table 2: Variable addition Chi2 test from canonical co-integrating regression.

\section{Empirical optimal control model - results}

The optimal control model was solved and simulated for the following four scenarios using deterministic numerical computational algorithms. Results of the model can be summarized as follows:

1. Continuous potatoes. This rotation is not sustainable over the long run. The model treats nitrogen naturally occurring in the soil differently than nitrogen fertilizer and natural nitrogen is a necessary factor of production. Since the only way to enhance this source of nitrogen is through the growth of grain or forage, eventually the increase in the future value of entering another crop into the rotation outweighs the current profit of growing potatoes. While continuous potatoes does not lead to a steady-state rotation, it can be sustained over the short term, particularly if natural nitrogen levels in the soil are high. This may be true of land that has recently been brought into production, like land in the eastern part of PEI.

2. Two crop rotation: potato and grain. This crop rotation dominates the simulation results. It also leads to a steady state level of nitrogen and a steady state rotation. Therefore, it is sustainable. However, this rotation also leads to a significant amount of pollution from nitrogen runoff. This crop rotation is likely to result in continued interference of agriculture on other industries in PEI and therefore agriculture or other industry conflicts may remain. There is evidence of an anecdotal nature that this rotation is highly prevalent in PEI. Profitability of this crop rotation is highest.

3. Two crop rotation: potato and forage. The results show that this crop rotation is rarely optimal. Much of the reason that forage never enters the rotation is due to the fact that forage is treated as a green manure. Therefore, forage enters the rotation when it is given some value other than simply its conservative effects on soil quality. The steady state level of nitrogen is highest with this rotation, while discounted present value of profits is lowest.

4. Three crop rotation: potato, grain, and forage. The results show that this crop rotation is never optimal. When forage enters the rotation, grain leaves, implying that a three crop rotation is never optimal. There is anecdotal evidence that three crop rotations are not the dominant in PEI, which suggests that grain/forage interactions may not be economically important to the explanation of observed PEI crop rotations.

Results from analyzed scenarios suggest that in order to bring in the most soil conserving crop rotation (potato-grain-forage), certain compensations are needed.

The economy aspects of mandatory crops rotation - farmers' decision making process

In order to evaluate crop rotation policy options and implications, it is necessary to determine the crop rotation given the model assumptions. Clearly, the crop rotation depends on the settings of the model. It is apparent that there is an indefinite 
combination of settings; for example, conditional on different initial nitrogen level, different input/ output prices, or interest rate. Six different scenarios were created to simulate various exemplary situations; settings and simulation results under these scenarios are presented in Table 3.

The first two scenarios are created to represent differences in the behavior of farmers, depending on different initial levels of soil nitrogen. This may illustrate the situation in the Eastern part of the province, where land was recently brought into production. The third and fourth scenarios represent the effects of interest rate change. The fifth scenario represents an increase in the output price of potatoes. The last scenario demonstrates an increase in the input price of nitrogen fertilizer. While the results provide an explanation as to what is the optimal crop rotation, it also shows that ceteris paribus initial soil conditions matter. Hence, when a mandated crop rotation land use policy is introduced, those farmers who previously rotated the crops and maintained high soil quality may be disqualified. The simulation is further expanded to include the changes in output prices, as in the market environment agricultural producers have to face oscillating prices. In the presence of a market-based environment, mandatory fixed crop rotations have important economic impacts. For the purpose of demonstrating how the mandatory fixed rotation affects farmers when prices are not assumed to be fixed, random number generated data is used. Specifically, potato and barley prices were randomly generated based on a historical mean price, and its standard deviation. The process of random number generation also implements stochastic behavior into an otherwise deterministic model. The simulation yields approximately $83 \%$ potatoes as the optimal long-run average rotation (potatoes are grown on average once every three years over the entire optimization horizon). The same pattern of approximately $83 \%$ is also used for the fixed rotation simulation (potatoes are grown only once every three years consecutively). As expected, the profits associated with simulation based on the fixed rotation pattern are smaller. The difference in the profits between them is approximately $15 \%$. Environmental approach is determining the farmers' economy activities stricture and their profit. The reduction of potato producing areas is reducing profitability. If farmers would produce potatoes on $100 \%$ of available plots their profits per acre would be significantly higher in comparison to mandatory crops rotation system (e.g. compare scenario 1 and scenario 3 ).

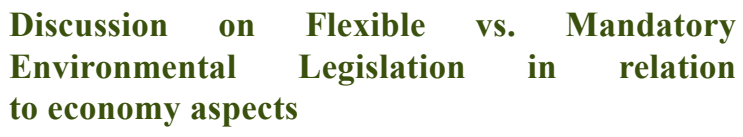

Furthermore, the results can explain why there is resistance by producers to the mandated three year fixed crop rotations instituted by the PEI government. In order to explain the resistance,

\begin{tabular}{|c|c|c|c|c|c|c|c|}
\hline & & \multicolumn{6}{|c|}{ Scenarios } \\
\hline & & 1 & 2 & 3 & 4 & 5 & 6 \\
\hline \multicolumn{8}{|l|}{ Model inputs } \\
\hline Interest rate & (\% p.a.) & 5 & 5 & 10 & 2 & 5 & 5 \\
\hline Time horizon & (years) & 300 & 300 & 300 & 300 & 300 & 300 \\
\hline Initial nitrogen level & (lb/acre) & 500 & 6000 & 500 & 500 & 500 & 500 \\
\hline Output price potatoes & $(\$ / 1 b)$ & 0.1 & 0.1 & 0.1 & 0.1 & 0.15 & 0.1 \\
\hline Output price barley & $(\$ / 1 b)$ & 0.05 & 0.05 & 0.05 & 0.05 & 0.05 & 0.05 \\
\hline Output price forage & $(\$ / l b)$ & 0.0001 & 0.0001 & 0.0001 & 0.0001 & 0.0001 & 0.0001 \\
\hline Input price fertilizer & $(\$ / 1 b)$ & 0.5 & 0.5 & 0.5 & 0.5 & 0.5 & 1 \\
\hline \multicolumn{8}{|l|}{$\begin{array}{ll}\text { Model outputs } \\
\end{array}$} \\
\hline \multicolumn{8}{|l|}{ Optimal crop rotation } \\
\hline$\%$ potatoes & & 72 & 81 & 100 & 79 & 79 & 73 \\
\hline$\%$ barley & & 28 & 19 & 0 & 21 & 21 & 27 \\
\hline$\%$ forage & & 0 & 0 & 0 & 0 & 0 & 0 \\
\hline Steady state nitrogen stock & (lb/acre) & 1600 & 700 & $\mathrm{t}=>$ inf & 1300 & 1300 & 1600 \\
\hline Discounted present value of profits & (\$/acre) & 44790 & 117728 & 197930 & 129404 & 129404 & 43780 \\
\hline
\end{tabular}

Table 3: Simulation results. 
it is necessary to introduce a stochastic element into the model in the form of randomly generated prices. Several rotation scenarios were modeled using this approach. One crop rotation scenario involves a flexible crop rotation where farmers are allowed to react to short-run price fluctuation. The other crop rotation simulates a fixed mandatory crop rotation as proposed by PEI legislation. Comparison of these rotations highlights two different views of crop rotations. Finally, scenarios were generated with different initial soil conditions. Under fixed crop rotation systems, crop rotations are viewed as non-stochastic in nature and adhered to because of their biophysical impacts on soil and other environmental factors. Farmers are assumed to strictly adhere to a particular regimen that is independent of stochastic fluctuations in prices and other variables that may affect the short-run competitiveness of a crop in a rotation, but not its long-run average competitiveness in the rotation. Under flexible crop rotation systems, a rotation is defined as an average amount of time a crop enters a rotation and therefore is not deterministic, but is stochastic in nature. Hence, although in the short-run a particular crop may deviate from its long-run mean in the rotation due to short-run fluctuations, over the long-run mean reversion will result. Ceterus paribus, flexible crop rotations, and fixed crop rotations generate similar long-run results and so the long-run environmental impacts of both of these systems is, for the most part, environmentally neutral. However, since flexible crop rotation systems allow producers to make short-run adjustments in crop decisions given relative prices that are excluded in fixed crop systems, in stochastic environments, flexible crop rotation systems will maximize returns to producers and fixed crop systems will not. In simulated results for PEI where potatoes entered the rotation once in three years on average, fixed crop rotation systems yielded a $20 \%$ loss in wealth as compared to flexible crop rotation systems. In the case of different initial soil quality, the results indicate that farmers who are not allowed to use expendable surpluses from their soil, i.e. part of soil that is not economic to regenerate, may suffer economic loss up to $50 \%$, as opposed to cases when abundant soil quality is used until equilibrium is attained. The results of the optimal control model indicate that there are important costs associated with mandated crop rotations that may explain why there is resistance by producers to this legislation in PEI. The results indicate that the choice of crop in rotation is very much an entrepreneurial decision. If this aspect of the production decision making is taken out of the hands of producers through mandated crop rotations, significant losses may result. Furthermore, flexible crop rotation and fixed crop rotation systems generate similar long term environmental impacts. The losses to producers are not transferred into environmental gains. They are therefore a deadweight loss associated with the implementation of a fixed crop rotation rather than flexible crop rotation systems. Given that rotations mandated by the PEI government represent fixed crop rotation systems, this policy may be inefficient when compared to one where flex cropping is allowed.

Crops rotation as positive factor/as positive externality

The application of crops rotation is not only the problem of Canada. Crops rotation in nowadays is also very important topic discussed at the level of FAO, WTO and also the EU. However farmers attitude to mandatory crops rotation is not really positive, crops rotation is able to generate the significant externalities. The value of those externalities is estimated to be much higher than the farmers' loses. There are several positives related to crops rotation.

- Crop rotation improves soil structure, soil fertility and biodiversity over time, preventing the build - up of pathogens and pests and decreasing pesticide use and water pollution (Ulmer, 2013).

- Where leguminous plants are part of crop rotation schemes, significant amounts of energy - intensive and increasingly expensive mineral fertilizer can be replaced by natural nitrogen fixation. This decreases the risk of nitrogen leaking into water bodies and prevents emissions of $\mathrm{N} 2 \mathrm{O}$ and other NOx gases into the atmosphere, these being among the most potent greenhouse gases (Ulmer, 2013).

- While there is almost universal agreement among experts that crop rotation provides a variety of environmental and agronomic benefits, the crop diversification plan currently proposed by global authorities, now being discussed by the stakeholders, not only offers inferior agro-environmental results, but also creates a diversity of additional agronomic management problems, especially for small holdings (Ulmer, 2013).

- Crop rotation fully complies with WTO 
green box requirements when the focus of any proposed greening measure remains on the environmental function and intended agro-ecological results of crops rotation, which is the most tangible and locally measurable benefit of crop rotation (Ulmer, 2013).

- Mandatory crop rotation, which includes plants that have demonstrated positive environmental and agro-ecological functions, may thus put government subsidies/payments on an even safer and more legitimate footing (Ulmer, 2013).

\section{Conclusion}

The results coming from the analysis suggest that potato production in PEI can be a source of watercourse pollution. These results support the actions of the Round Table of PEI's government to introduce legislation to protect the environment and maintain its high quality. If no actions are taken, the environment in PEI can be degraded and non agricultural sectors depending on high living environment quality (e.g. tourism industry) may sustain significant losses associated with agricultural interference. PEI was supposed to serve as a template for other Canadian provinces with regards to the Agricultural Crop Rotation Act, the first legislation of its kind in North America that was supposed to limit the negative environmental impacts of agricultural production, where producers carry its costs. Based on the conducted analysis, mandatory crop rotations legislation, as introduced by PEI government in the Agricultural Crop Rotation Act, is likely to meet with farmers' resistance. Each year, producers face a decision as to what crop to grow. At that time, decisions are made as to the tradeoff of present profit based on current market conditions compared to expected future profit. Mandated rotations take this decision out of the hands of producers, without compensation. Furthermore, mandated rotations are based on an assumption of a steady state outcome that may not be relevant to producers who have recently brought land into production. Continuous potatoes may be optimal for these producers in the short run until liquidation values of natural stocks of nitrogen are exhausted. For this reason alone, mandated rotations are likely to meet with resistance from producers. Mandated rotations largely take quantity decisions out of the hands of producers and place them in the hands of government. However, producers are left to bear the costs of not being able to take advantage of price fluctuations. In this sense, mandated rotations may be perceived as unfair by producers. Cases where quantity decisions are mandated by the government with the support of producers are the supply managed industries. Under supply management, the government takes on the responsibility of controlling price through the control of quantity. If the Provincial government were willing to finance a guaranteed price support along with mandating rotations, crop rotation legislation may have more support from producers. Guaranteed prices for producers may be a reason why mandated crop rotations are not opposed in the European Union. In the absence of price supports, together with mandated rotations, the more flexible approach would be the use of taxes and subsidies without mandated rotations. Market based approaches influence producer behavior and enhances the goals of environmental preservation over the long term without taking from producers the potential gains resulting from short term market fluctuations. Therefore, flexibility is left with producers to adjust rotations as market conditions arise and can therefore result in increases in producer welfare without destroying long-run environmental targets of society. As the European Union shifts away from agricultural subsidies schemes towards market based approaches, legislators may find agricultural producers to be reluctant to follow fixed environmental policies. In this sense, analysis of mandatory crop rotations in Prince Edward Island may serve as an example for policy makers on how to adjust environmental policies in the presence of market based environment.

\section{Acknowledgements}

This paper was prepared within the project 20151016 - Establishing food security for Bangladesh's rural poor through sustainable collective farming practices. The project is supported by FEM, CULS in Prague, Internal Grant Agency. 
Corresponding author:

Ing. Petr Procházka, Ph.D.

Department of Economics, Faculty of Economics and Management,

Czech University of Life Sciences in Prague, Kamýcká 129, 165 21, Prague, Czech Republic

E-mail:pprochazka@pef.czu.cz

Ing. Helena Řezbova, Ph.D.

Department of Economics, Faculty of Economics and Management,

Czech University of Life Sciences in Prague, Kamýcká 129, 165 21, Prague, Czech Republic

E-mail: rezbova@pef.czu.cz

Doc. Ing. Luboš Smutka, Ph.D.

Department of Economics, Faculty of Economics and Management,

Czech University of Life Sciences in Prague, Kamýcká 129, 165 21, Prague, Czech Republic

E-mail: smutka@pef.czu.cz.

\section{References}

[1] BAAP (Baltic Agricultural run-off Action Programme). About BAAP, 2003. [Online]. Available: http://www.baap.lt [Accessed: 12 December 2014].

[2] Canadian Broadcasting Corporation. PEI Introducing Crop Rotation Legislation, 2001. [Online]. Available: http://www.cbc.ca/news/story [Accessed: 30 December 2014].

[3] Canadian Broadcasting Corporation. Second P.E.I. fish kill uncovered, 2007a. [Online]. Available: http://www.cbc.ca [Accessed: 10 November 2014].

[4] Canadian Broadcasting Corporation. Buffers not enough to stop fish kills. 2007b. [Online]. Available: http://www.cbc.ca/canada [Accessed: 10 November 2014].

[5] Canadian Broadcasting Corporation. Fish kill unfortunate, says minister, 2007c. [Online]. Available: http://www.cbc.ca [Accessed: 10 November 2014].

[6] Clark, J. S., Cechura, L., Thompson, S. J. Induced Innovation in Canadian Agriculture. Book Group Author(s): Czech Univ Life Sci Prague, Fac Econ \& Management Conference: Joint Conference on $21^{\text {st }}$ International Scientific Conference on Agrarian Perspectives / $131^{\text {st }}$ EAAE Seminar Location: Prague, Czech Republic Date: Sep. 18-19, 2012. ISBN 978-80-213-2370-4

[7] Crist, S., Monroe, R., Poats, J., Environmental impacts of septic systems, 1999. [Online]. Available: http://www.cee.vt.edu/ewr [Accessed: 10 September 2014].

[8] Dickey, D. A., Fuller, W. A., Distribution of the estimators of auto-regressive time series with a unit root. Journal of American Statistical Associaton. 1979, No. 74, p. 427-431, ISSN 0162-1459.

[9] Environment Canada. Prince Edward Island Water Quality Program, 2007. [Online]. Available: online: http://www.gov.pe.ca [Accessed: 10 January 2015].

[10] Fertilizer Institute. About Fertilizer, 2007. [Online]. Available: http://www.tfi.org. [Accessed: 3 December 2014].

[11] Government of PEI. Potato industry fact book, 2002. [Online]. Available: http://www.gov.pe.ca/af [Accessed: 10 August 2011].

[12] Granger, C. W. J. Time Series Analysis - Cointegration and Application, 2002 (The Nobel Lecture). Stockholm, Sweden. [Online]. Available: http://www.eco.uc3m.es/ jgonzalo/teaching/ EconometriaII/GrangerNobelTalk.pdf [Accessed: 10 November 2014].

[13] Jatoe, J., Yiridoe, E., Weersink, A., Clark, J. S. Economic and Environmental Impacts of Introducing Land Use Policies and Rotations on Prince Edward Island Potato Farms. Land Use Policy, 2008, No. 25, p. 309-319. ISSN 0264-8377. 
[14] Lake Winnipeg Stewardship Board. Lake Science, 2008. [Online]. Available: http://www. lakewinnipeg.org/web/downloads [Accessed: 10 January 2011].

[15] Park, J. Y. Canonical Cointegrating Regressions. Econometrica, 1992, Vol. 60, No. 1, p. 119-143, ISSN 1468-0262.

[16] PEI Government. Round Table on Resource Land Use and Stewardship, 2007. [Online]. Available: http://www.gov.pe.ca [Accessed: 30 December 2011].

[17] PEI Government. Land Use Policy, 2002. [Online]. Available: http://gov.pe.ca/af/agweb.html [Accessed: 10 December 2011].

[18] Prince Edward Island Provincial Treasury. Annual Statistical Review 2013-2014, 2014. [Online]. Available: http://www.gov.pe.ca [Accessed: 10 January 2014].

[19] Svatoš, M. Selected trends forming European agriculture. Agric. Econ. - Czech, 2008, Vol. 54, No. 3, p. 93-101. ISSN 0139-570X.

[20] Statistics Canada. E-STAT, Canadian Socio-economic Information Management System, 2007. [Online]. Available: http://estat.statcan.ca/ [Accessed: 10 August 2011].

[21] Ulmer, K. Global Food Security - Crop Rotation in the CAP reform: Relevance of WTO Constraints, Benefits and Control, 2013. [Online]. Available: http://aprodev.eu/files/Trade/aprodev\%20 croprotationinthecapreform_wtoconstraintsandcontrol_finalfeb2013.pdf [Accessed: 22 June 2015]. 